\title{
“A LIBERDADE DENTRO DA FÉ": Cristianismo, poesia e contemporaneidade em Murilo Mendes
}

\author{
"FREEDOM IN THE FAITH": CHRISTIANITY, POETRY AND CONTEMPORARY IN MURILO MENDES
}

Luciano Costa Santos ${ }^{(*)}$

\begin{abstract}
RESUMO
Murilo Mendes se sobressai como um dos mais inventivos poetas brasileiros contemporâneos de matriz modernista. Por isso, causou estranheza a publicação de "Tempo e Eternidade" (1935), sob o lema "Restauremos a poesia em Cristo", cuja impostação aparentemente reativa sugere haver o poeta renegado sua condição moderna e, ao menos, restringido a vocação artística. Não obstante, tal viragem estético-existencial intensifica características estilísticas e abre outras zonas de sensibilidade e horizontes temáticos em sua poesia, operando uma transfiguração simbólica que nem lhe desfibra o élan criador, nem doma sua insubmissa virulência. A "restauração" da poesia "em Cristo" não capitula a liberdade criadora do poeta a uma férrea ordem metafísica prévia, mas propicia-lhe o encontro com uma inaudita potência redentora de sentido que lhe dá novos e definitivos motivos para cantar. Ao conciliar liberdade e fé, criação e reverência e, por extensão, homem e Deus, tempo e eternidade etc., convertendo a suposta contradição em tenso e fecundo contraste, a poesia de Murilo Mendes descortina uma promissora perspectiva de leitura do mistério cristão que aqui denominamos transmoderna, a qual, sem ser anti-moderna ou "reacionária" - por assumir a aventura da liberdade na vertigem dos tempos atuais -, vai além do paradigma moderno, ao retirar o sujeito de sua esterilizante auto-suficiência e abri-lo a um permanente diálogo com a transcendência.Tal chave hermenêutica é demonstrada a partir de uma abordagem das principais fases e obras do autor.

Palavras Chave: Murilo Mendes. Cristianismo. Poesia. Contemporaneidade.
\end{abstract}

\begin{abstract}
Murilo Mendes stands out as one of the most inventive contemporary Brazilian poets of modernist matrix. So it was surprising the publication of "Time and Eternity" (1935), under the slogan "Let us restore poetry in Christ", whose seemingly reactive tone suggests that there the poet disowned its modern condition and at least restricted the artistic vocation. However, this aesthetic-existential turning intensifies stylistic features and opens other sensitive areas and thematic horizons in his poetry, operating a symbolic transfiguration without defibering his creator elan, or taming your unruly virulence. The "restoration" of poetry "in Christ" not capitulates the creative freedom of the poet to an prior metaphysics order, but provides you the encounter with an unprecedented redemptive power of meaning that gives you new and definitive reason to sing. To reconcile freedom and faith, creation and reverence, and by extension, God and man, time and eternity etc., converting the supposed contradiction in tense and fruitful contrast, the poetry of Murilo Mendes reveals a promising reading perspective of the Christian mystery here we call transmodern, which, without being anti-modern or "reactionary" - to take on the adventure of freedom in the vertigo of the times -, goes beyond the modern paradigm, to remove the subject of a sterillant self-sufficiency and open it an ongoing dialogue with transcendence. This hermeneutical key is demonstrated from an approach of the principal phases and works of the author.
\end{abstract}

KEYWORDS: Murilo Mendes. Christianity. Poetry. Contemporaneity.

${ }^{(*)}$ Doutor em Filosofia. Professor de Filosofia do Programa de Pós-Graduação em Educação e Contemporaneidade da Universidade do Estado da Bahia. Email: lucostasantos@gmail.com 


\section{INTRODUÇÃO}

A Igreja Católica marcou sua presença nas primeiras décadas do século XX, no Brasil, sob o signo da Reação e da Ordem. Diante do intenso processo de modernização que ameaçava minar os fundamentos da Cristandade ocidental em terras tropicais, coube ao Arcebispo do Rio de Janeiro, D. Sebastião Leme, chamar para si a responsabilidade de chacoalhar a grande maioria católica, "inoperante e asfixiada", e comandar a retomada do protagonismo social da Igreja. Em duas principais linhas de frente: o investimento na educação católica, enfraquecida desde a supressão do ensino religioso na escola pública pela Constituição de 1891; e a organização de uma "armada" de intelectuais leigos incumbida da formação doutrinária de setores estratégicos da sociedade. Os principais frutos dessa iniciativa eclesiástica foram a publicação, em 1921, da revista A Ordem e, um ano depois, a fundação do Centro D. Vital, respectivamente emissário oficial e principal núcleo aglutinador da intelligentsia católica no Brasil, que abriram caminho à sólida e abrangente intervenção pastoral da Ação Católica na década seguinte.

Em meio ao surto de industrialização e urbanização, que despertava o Brasil de seu letárgico sono feudal, D. Leme concebe a Igreja como uma cidadela espiritual plantada na vertigem de nossa terra em transe, encarregada de conter as vagas de secularismo racionalista - fosse de vertente liberal, positivista ou marxista - que ameaçariam arrancar a nação brasileira de suas matrizes espirituais de origem. Em suma, tratava-se de assegurar à moderna civilização brasileira, então nascente, a mesma contenção simbólica que, na França, a Action Catholique de Charles Maurras pretendia trazer às ondas de secularismo provenientes da Revolução Francesa. Nesse contexto, ao intelectual católico caberia ser, a um tempo, guardião da Tradição, sentinela da Ortodoxia e combatente a serviço da Ordem.

A Igreja da Reação e da Ordem encontrou sua genial personificação na figura do escritor sergipano Jackson de Figueiredo (1893-1928). De passado anarquista e anticlerical, Jackson aderiu às hostes católicas após uma conversão de toque paulino, passando a defender a Igreja com a mesma veemência com que antes a combatia. Líder carismático, escritor profundo e bravo polemista, foi alçado por $\mathrm{D}$. Leme à direção de $A$ Ordem e do Centro D. Vital, nela permanecendo até a sua morte precoce, por afogamento, em fins da década de 1920. Cioso da missão de restaurar o primado da Cristandade em plenos tempos modernos, Jackson qualifica o seu pensamento - literalmente - de "reacionário", sem dar ao termo o sentido pejorativo que mais tarde o caracterizaria. Pelo contrário, a atitude de reação parecia-lhe um atestado de autenticidade, por ser o único modo possível de permanecer recolhido às fontes da fé em meio ao irreversível desarraigo moderno. 
O patriarcado espiritual de Jackson de Figueiredo imprimiu funda marca no laicato católico, que perdurou mesmo após a morte do mestre sergipano. Por isso, no ambiente eclesial ainda fortemente imantado à sua personalidade "reacionária", em meados da década de 1930, não poderia senão causar estranheza a (re) conversão ao catolicismo de um dos mais expressivos artistas filiados ao modernismo de 1922: o poeta mineiro Murilo Mendes (1901-1975). Tanto quanto a conversão de Murilo em si mesma, o que desconcertava era o fato de, ao dobrar os joelhos ante o Mistério, o poeta não haver arrefecido a potência criadora de sua arte ou lhe domado a insubmissão vanguardista, trazendo uma perturbadora dissonância ao afinado coro dos católicos da Ordem. À sombra de Jackson, não parecia sequer concebível que semelhante espírito revolucionário pudesse vir a pertencer a uma tradição espiritual ou sujeitar-se a uma autoridade que, em última instância, não tivessem no próprio sujeito a sua fonte de legitimação. E, no entanto, o mineiro Murilo (re) encontrava nos imemoriais veios da fé cristã preciosas matrizes de sentido que lhe davam novos motivos líricos e imprevistos princípios utópicos. Encontrava, assim, o novo no eterno, e abria passagem ao futuro a partir da pertença aos arcanos da revelação. Ligava tradição e revolução, reverência e rebeldia, pertença e ruptura, fé e liberdade. Descobria, enfim, um secreto elo vital entre catolicismo e modernidade. Mais que acontecimento insólito, o reencontro do poeta com o catolicismo portava uma ruptura paradigmática que desacomodava as próprias identidades "católica" e "moderna", tais como estas até então se configuravam, abrindo uma via terceira diante da antinomia cristalizada entre o catolicismo anti-moderno d'A Ordem e o modernismo anticlerical de linhagem oswaldiana.

A caminho dessa via terceira transitada por Murilo Mendes, que aqui arriscaremos chamar de transmoderna, consideremos primeiro a sua apropriação da modernidade, em seguida sua (re)conversão ao catolicismo e, então, o diálogo que promoveu entre essas filiações estética e religiosa, e alguns de seus principais desdobramentos conceituais.

\section{MURILO MODERNO}

Murilo Mendes se sobressai como um dos mais inventivos poetas brasileiros contemporâneos, considerado por Manuel Bandeira um dos "bichos-da-seda" de nossa literatura, isto é, "os que tiram tudo de si mesmos”.(MENDES, 1994, p. 35).Entre nossos escritores, foi um dos mais extremos exemplos de poeta em tempo integral, fazendo da literatura não somente o seu exclusivo ofício, mas a sua profissão de fé. ${ }^{1}$ Criador ingênito,

\footnotetext{
1“Tinha uma intuição obscura de que estava mesmo destinado a ser escritor. Agora que é de moda entre tantos escritores esnobar a literatura, continuo a fazer profissão de fé literária. Afronto mesmo o ridículo do pejorativo: fui e sou literato desde o ventre de minha mãe.” MENDES, Murilo, 1994, p. 926.
} 
dotado de "feroz independência de espírito" (ARAÚJO, 2000, p. 69), absteve-se de aderir formalmente a qualquer programa ou manifesto literário, embora desde a obra de estreia a sua lírica se afeiçoasse com natural desenvoltura ao verso livre e a outros legados modernistas. ${ }^{2}$ Com Oswald de Andrade e Carlos Drummond, filia-se ao núcleo anarcovanguardista do modernismo - isto é, "ao núcleo puro e duro de modernidade radical”(MENDES, 1994, p. 11)-, chegando a incursionar pelo poema-piada no episódico "História do Brasil" (1932), à lamanière de Oswald, sem que esse filão pitoresco chegasse a fazer fortuna em sua obra.

Amante inveterado das artes, Murilo tinha compulsão pela beleza em suas mais variadas manifestações, fazendo especialmente da música o seu pão cotidiano. Cultivou por toda a vida uma lendária devoção a Mozart, a quem afiançava haver visto em sua pensão no bairro de Botafogo. Ainda adolescente, foge do colégio interno, em Niterói,para assistir a apresentação do bailarino Nijinski no Teatro Municipal do Rio de Janeiro, fato que exerce sobre ele impacto estético somente comparável à passagem do cometa Halley, aos nove anos, em Juiz de Fora, cuja mirífica aparição, no limiar entre o visível e o invisível, o "desperta para a poesia". ${ }^{3}$ Desbravador de estilos e linguagens, pesquisa, assimila e decanta as mais diversas vertentes de vanguarda do século $\mathrm{XX}$, chegando a incorporar com maestria elementos da estética surrealista, em incansável busca da melhor expressão de seu estro libertário. Desse ponto de vista, toda sua vida não é senão uma aventurosa consagração às possibilidades da Linguagem. O maior reconhecimento de tamanha dedicação veio-lhe em 1972, três anos antes de sua morte, com a outorga do Prêmio Internacional de Poesia Etna-Taormina, dos mais importantes da Europa, quando o poeta lá residia, atuando como professor de Cultura Brasileira na Universidade de Roma desde fins da década de 1950.

No que se refere a suas referências, a obra poética de Murilo Mendes pode ser lida como vasto compêndio de estética modernista, a qual tem entre suas principais características: a concepção da arte como criação pura - ao artista cabe deixar vir à linguagem o que precisa ser dito, sem sujeitar o moto lírico a ideias ou objetivos prévios; experimentação formal, que insta à permanente pesquisa das possibilidades expressivas de cada arte, a exemplo do verso livre em campo literário; autonomia da arte - a obra não é cópia das coisas percebidas, mas instaura a sua própria realidade enquanto invenção; e intensificação do estilo singular de cada artista, evitando-se a passiva acomodação do eu lírico a formas pré-moldadas.

\footnotetext{
${ }^{2}$ Segundo José Guilherme Merquior, Murilo Mendes, como Carlos Drummond de Andrade, "já nasceram modernistas”. MERQUIOR, José Guilherme. "Notas para uma Muriloscopia”. In MENDES, M., 1994, p. 11.

3“O cometa me traz o anúncio de outros mundos/e de noite eu não durmo/ atrapalhado com o mistério das coisas visíveis./ No rabo imenso do cometa/ passa a luz, passa a poesia, todo o mundo passa!”. MENDES, M., 1994, p. 124.
} 
Em suma, no núcleo gerador da estética modernista encontra-se o elã de liberação, cuja face mais visível - a negativa, liberação de - não é senão a contrapartida de sua dimensão originária - a propositiva, liberação para. Trata-se, portanto, de liberar a obra da imitação servil do modelo "real" para a sua afirmação como realidade inventada; de liberar o sujeito da sujeição a esquemas formais para a descoberta de seu estilo único; enfim, de liberar o próprio jogo da arte da subordinação a objetivos pré-estabelecidos para a sua afirmação como gesto criador. Assim, não há geração do novo - obra - sem a desobstrução de esquemas, modelos, conceitos, certezas, expectativas, que o impeçam de vir à luz; noutras palavras, o esvaziamento é o preço da fecundidade artística, e sem rebeldia não há criação.

Não por acaso, a insígnia do poeta - e título de uma de suas mais importantes obras, publicada em 1947 - chama-se "Poesia Liberdade".

Outra importante marca moderna, presente na obra de Murilo Mendes, é o desarraigo das matrizes culturais de origem.

Resultado da expansão planetária das engrenagens técnico-industriais da sociedade de mercado, a civilização moderna opera um "desencaixe"4 entre o espaço mundial e os territórios de origem. Cada vez mais, pessoas de distintas proveniências transitam no mesmo circuito hegemônico de técnicas, códigos, produtos, valores, numa diluição geral de fronteiras e diferenças. Arrebatado pelo fluxo do tempo global, mal é dado ao sujeito nascer no próprio lugar, demorar-se nos ritmos de sua gente, pertencer à sua história. Por vezes, o mundo se lhe torna mais familiar que a paisagem nativa. $O$ homem contemporâneo - muito especialmente em países colonizados, de civilização transplantada - vê-se clivado pela dupla exigência de ascender à modernidade, com suas irrecusáveis conquistas, e resistir à tendência de romper laços com o núcleo ético-mítico da cultura matriz, em que se recolhem camadas profundas de sua identidade. Desafio exemplarmente resumido pelo filósofo Paul Ricoeur: "É fato: nem toda cultura pode suportar e absorver o choque da civilização mundial. Eis o paradoxo: como modernizar-se e retornar às fontes? Como despertar uma velha cultura adormecida e entrar na civilização mundial?”(RICOEUR, 1968, p. 284).

Embora tenha flertado com motivos regionais em "Bumba-meu-poeta" (1931) e "História do Brasil" (1932), e por mais que trouxesse o barroco das Minas na medula de sua lira - como o atesta essa viagem étnico-espiritual que é "Contemplação de Ouro Preto" $(1950)^{5}$-, Murilo não é o cantor do povo de um lugar. ${ }^{6}$ Não finca a inspiração no chão. À

\footnotetext{
4 O termo é empregado pelo sociólogo Anthony Giddens em sua obra Consequências da Modernidade. São Paulo: Ed. UNESP, 1991, p. 25 e ss.

5"Minha alma sobe ladeiras,/ Minha alma desce ladeiras/ Com uma candeia na mão,/ Procurando nas igrejas/ Da cidade e do sertão/ O gênio das Minas Gerais/ Que marcou estas paragens,/ Estas sombras
} 
margem do telúrico lirismo romântico e do projeto (da segunda fase) modernista de construção da identidade nacional, a sua alma já desperta exilada e não se demora na memória comum: "Monstros complicados/ não povoaram meus sonhos de criança/ porque o saci-pererê não fazia mal a ninguém/ [...]/ Fiquei sem tradição sem costumes nem lendas/ estou diante do mundo/ deitado na rede mole/ Que todos os países embalançam.” (MENDES, 1994, p. 88).

Desinstalado do abrigo provinciano pelo cósmico estupor do Halley, Murilo cedo conjuga a intrínseca solidão do eu: "O cometa passa e arrasta um pouco da minha alma,/ fiquei triste, triste, jururu!” (MENDES, 1994, p. 124). Descobre-se estrangeiro e peregrino no mundo. $\mathrm{O}$ que de algum modo se espelha no crônico nomadismo profissional e no intenso périplo internacional de sua errática biografia. ${ }^{7}$ Como o Pessoa de "Noite de São João", o poeta cosmopolita se sabe preterido dos ritos da tribo: "Noite de São João para além do muro do meu quintal./ Do lado de cá, eu sem noite de São João.” (PESSOA, 1960, p. 173).

O sentimento que reponta na obra de Murilo Mendes pela década de 1930 afora não é, pois, propriamente de saudade, mas de difusa angústia ante um mundo agônico que apenas começava a nascer. Ao passo que a saudade tem alvo - é saudade disto ou daquilo -, na angústia a subjetividade faz a experiência de si mesma como pura possibilidade ou indeterminação radical. Enquanto a saudade se aplaca na reconquista do lugar perdido, a única saída para a angústia é aceitar o seu aguilhão e aventurar-se no desconhecido. Sem via de regresso ao lugar de origem, o poeta entrega-se à vertigem do tempo e, cometa desgarrado, faz-se habitante do caos: "Cairei no chão do século XX/ É a hora do protesto geral/ É a hora dos voos destruidores/ É a hora das barricadas, dos fuzilamentos/ Fomes desejos ânsias sonhos perdidos/ Misérias de todos os países uni-vos/ Fogem a galope anjos-aviões/ Carregando o cálice da esperança/ Tempo espaço firmes porque me abandonastes”. (MENDEs, 1994, p. 239). Noutras palavras, a Poesia Liberdade de Muriloé também "Poesia em Pânico". 8

Intelectualmente emancipado, esteticamente libertário, culturalmente desarraigado e em sintonia com os transes do tempo, Murilo filia-se a uma matriz de subjetividade moderna, marcada pela solidão ontológica do sujeito lançado ao mundo e avesso a

benfazejas,/ Estas frescas paisagens,/ Estes ares salutares,/ Lavados, finos, porosos,/ Minerais essenciais,/ Este silêncio e sossego,/ Estas montanhas severas,/ Esta antiga solidão,/ Com o sinal do seu lirismo,/ Com a cruz da sua paisagem." "Romance das Igrejas de Minas”. MENDES, M., 1994, p. 461.

${ }^{6}$ Alusão ao título da canção “Canto do povo de um lugar”, de Caetano Veloso.Álbum “Bicho”, 1977.

7Murilo Mendes trabalhou como telegrafista, guarda-livros, funcionário de cartório, professor de francês, arquivista, escriturário de Banco, não se demorando em nenhum emprego. Em 1957, passou a residir em Roma, percorrendo vários países da Europa até falecer em Lisboa, em 1975, onde foi sepultado.

${ }^{8}$ Título do livro de poemas publicado em 1937. 
qualquer sentido que lhe seja imposto anteriormente à sua livre apropriação de si mesmo. Difícil, portanto, conceber como alguém que tanto ousou insurgir-se contra formas caducas, assumir a insubmissa solidão do eu e entregar-se à transformação histórica em curso, veio a dar, em meados de 1930, respectivamente na Igreja da Ordem, da Autoridade e da Reação.

\section{O PAI E O PADRE}

Antes, porém, de examinar a (re)conversão de Murilo Mendes ao catolicismo e sua singular versão deste, advirta-se que o menino de Juiz de Fora recebeu em herança - na meia luz da infância - princípios axiais da fé cristã, aos quais posteriormente saberia dar os mais vigorosos desdobramentos:

Educam-me na religião católica, aos seis anos meu pai e o catequista transmitem-me uma informação fundamental, todos os homens são filhos do Pai celeste, iguais diante d'Ele, irmãos, remidos pelo sangue de Cristo, sem diferença de raça, credo, classe ou ideologia, mais tarde leio bibliotecas sobre religião cristã e outras, nenhuma doutrina me pareceu tão atual como aquela [...]. (MENDES, 1994, p. 916).

Tratando-se de espírito tão exigente como o seu, chama a atenção que lhe fosse possível haurir na simplicidade milenar do catecismo católico a doutrina mais "atual" dentre tantas aprendidas em "bibliotecas" devoradas ao longo da vida.

Da casa paterna, portanto, descortina-se ante o futuro escritor o horizonte utópico de fraternidade universal que será uma das inspirações permanentes de sua vida e obra. Em contraste com o modelo patriarcal hegemônico na sociedade brasileira do início do século, e com maior força na província, o inusitado pai-pedagogo do poeta, dotado de "qualidades de simpatia humana" e do "dom da comunicação" (MENDES, 1994, p. 971), que lia habitualmente "vidas de santos ou de grandes figuras leigas do catolicismo" (MENDES, 1994, p. 971), imprime-lhe fundo exemplo de abertura espiritual décadas antes do Concílio Vaticano II, numa atmosfera social em que a reatividade sectária tendia a bloquear o diálogo com os diferentes:

Que me legou meu pai de grande e permanente? Sem dúvida a religião católica, apresentada por ele, ao invés de certos padres, mais na sua flexibilidade do que na sua rigidez, incluindo o respeito pelas crenças ou descrenças alheias; o interesse pela pessoa espantosa de Jesus Cristo; a sensação, sempre renovada no catolicismo, de que me acho diante de questões formidáveis. Moviam meu pai, conservadorprogressista, a tradição, a grandeza de ânimo, a tolerância, a ternura antissentimental, o bom senso. Ouvindo-o nunca reparei que lhe faltava o canudo de doutor. Praticou a paz. Não a paz telegráfica e a de comícios; viveu a paz em música de câmara, amando-a total na sua carne e no seu espírito. (MENDES, 1994, 973). 
Dir-se-ia que germina aqui, nessa discreta articulação de tradição e flexibilidade, fidelidade e tolerância, operada na personalidade do católico Onofre Mendes, a nova identidade transmoderna - não propriamente "conservadora" ou "progressista", mas "conservadora"-"progressista" - que ao filho poeta, militante contracultural embarcado na viagem pânica do século XX, caberia levar às últimas consequências.

Numa época em que a “opção preferencial pelos pobres” ainda não estava em pauta eclesiástica e o ethos social cristão não tendia a ir além de uma filantropia acomodatícia, outro rasgo espiritual visionário do pai do poeta é o seu transbordante senso de solidariedade, especialmente para com desvalidos e deserdados. Presidente das Conferências Vicentinas em Juiz de Fora, mesmo ciente do limite da assistência caritativa não perdia de vista sua exemplaridade profética:

Uma vez, sendo eu já moço, criticando diante de meu pai esta associação que ele presidia em Juizde Fora, respondeu-me com lucidez que Ozanam ao criar aquela entidade não pretendia resolver a questão social, mas pôr seus membros em contato imediato com a realidade da vida, fazendo-os tocar a miséria, treinando-os para futuros samaritanos. Reportei-me então a uma época anterior, quando meu pai nos levava (cada semana um filho, rotativamente) a uma ampla casa onde se acolhiam doentes, paralíticos, aleijados, tortos, manetas, pernetas, cancerosos, prépersonagens de Luis Buñuel, todos sustentados pela Conferência Vicentina. Meu pai traz-lhes gêneros, toma mil providências, trata-os com carinho, dando-lhes injeções de vida. Alimentado, segundo Shakespeare, do leite da ternura humana, não se contenta em pastorear seus filhos. (MENDES, 1994, p. 971-972).

Para que se tenha ideia do quanto o evangelho social de Onofre vingou no filho poeta, leia-se o trecho abaixo, extraído de um manuscrito endereçado à "Folha Carioca", postumamente recolhido por Pedro Nava e doado por este ao Arquivo Museu de Literatura da Fundação Casa de Rui Barbosa. O texto - sem data, mas ao que tudo indica posterior à conversão de Murilo - dir-se-ia extraído de documento redigido por assessores pastorais de Comunidades Eclesiais de Base. É - ao pé da letra - pura Teologia da Libertação, mesmo escrito com duas décadas de antecedência do Concílio Vaticano II:

Considero da maior importância uma ação de conjunto dos católicos - dos cristãos em geral - para que se enfrente e se procure solucionar os grandes problemas do nosso tempo (...) Urge a adoção de um vasto plano social, para que nunca mais se confunda a caridade evangélica com a farisaica filantropia burguesa. O coração de Jesus está cansado de receber insultos na pessoa de seus amigos prediletos - os pobres. Elevemos os pobres à sua dignidade natural; não os rebaixemos com uma esmola atirada por egoísmo e até com desprezo. Ação social e ação individual também. Sejamos os primeiros em todos os setores do grupo social. Trabalhemos por uma comunidade de homens livres. Trabalhemos para que a estrutura econômica não se oponha ao método de libertação evangélica. (Apud GUIMARÃES, 1986, p. 50).

No poema "O Cristo subterrâneo", de "Tempo Espanhol" (1958), lê-se ainda vestágios dessa herança paterna transubstanciados pela lira muriliana: "Descubro um 
Cristo secreto/ Que nasce na Espanha súbito./ É um Cristo quase secreto/ Que nasce das catacumbas/ Da Espanha não-oficial./ Nasce da falta de pão,/ Nasce da falta de vinho,/ Nasce da funda revolta/ Contida pela engrenagem/ Da roda de compressão./ Nasce da fé maltratada,/ Vagamente definida.” (MENDES, 1994, pp. 620-621).

Outra influência decisiva na primeira formação espiritual do poeta foi o padre Júlio Maria, amigo de seu pai, homem intrépido, que "despede raios contra o beatério, os políticos e o governo" (MENDES, 1994, p. 912), avesso à banalização dos ritos litúrgicos e à pieguice religiosa, de inteligência profunda e viril, responsável por fazê-lo entrever a gravidade teológica dos mistérios cristãos:

O padre Júlio Maria servira-me o vinho forte, desmamando-me para sempre do leite de uma religião afeminada e frouxa. Comecei aos poucos a compreender que a fé não nos traz o descanso, mas sim uma inquietude que somente cessará no último dia. $\mathrm{Ou}$ quem sabe nos sobreviverá? O amigo do meu pai inaugurava no Brasil o elenco de homens que através dos anos resumiriam a meus olhos a substância do catolicismo vivo (...). Depois, seja pessoalmente, seja através de livros, descobri inúmeros padres e leigos europeus que representam a fusão do catolicismo primitivo com a mentalidade moderna (...). Mas o padre Júlio Maria, a quem pude conhecer de perto num momento decisivo para a formação do meu espírito, na idade em que tudo se grava, foi o primeiro portador do fogo, o destruidor da imagem convencional do suave Nazareno e da lânguida Madona, o anunciador do Catolicismo como força violenta destinada a subverter a nossa tranquilidade e as próprias bases do mundo físico; o speaker do Apocalipse. (MENDES, 1994, p. 913).

À sombra do grande homem, o catolicismo saía do espaço da sacristia para revelarse como cosmovisão e projeto de formação do ser humano, enraizado em tradição milenar aberta às eras do porvir.

Espírito dialógico, fraternidade universal, solidariedade pelos excluídos, profundidade teológica, inquietude existencial, "fogo" transformador... Enfim, "catolicismo vivo", em "fusão com a mentalidade moderna", como "força violenta destinada a subverter nossa tranquilidade e as próprias bases do mundo físico": estava gerado o núcleo da personalidade espiritual do poeta por obra do pai e do padre. Restavalhe encontrar o amigo - ou o "Amigo", como às vezes o chamava - para que esse catolicismo vivo atingisse seu mais alto ponto de maturação.

A contraface da formação espiritual de Murilo Mendes é a repulsa cedo manifesta ao "outro" catolicismo - reativo, disciplinador, uniformizador - exercido como instrumento de controle social, que subjuga e sufoca o livre desabrochar da personalidade. A religião do "servilismo e da incapacidade de indignar-se"; dos "tiranos, inquisidores, absolutistas e dos cristãos servos do poder temporal”, que estão entre os tipos históricos mais abomináveis, conforme declara no "Questionário Proust”. (MENDES, 1994, p. 52). Um dos símbolos desse catolicismo morto e mortífero, a seu ver, é o confessionário usado como 
mecanismo de policiamento moral e "teatro de crueldade", no qual "evapora-se a poesia da vida e já não se pode gozar a delícia do segredo” (MENDES, 1994, p. 938):

[...] o confessor na Academia é o padre Solano, alemão, vermelho, duro, rigoroso, olho que arde; martela energicamente a palavra pecado, brande a terrível palavra concupiscência, espaventosas frases de São Basílio e Santo Agostinho sobre o fogo absoluto do inferno, as esdrúxulas metamorfoses dos danados, a rejeição da graça, aperta o saca-rolhas das perguntas, em particular as relativas ao sexto mandamento, minuciosas, estatísticas [...]. No fim das contas o torcionário usando naquela operação o saca-rolhas, o serrote, a torquês, a verruma, o martelo das palavras, tornou-se-me sem saber muito útil, passei a odiar por tangência toda e qualquer espécie de tortura; digo mais, o uso-abuso da tortura me faz desconfiar que o homem foi criado à dessemelhança de Deus. (MENDES, 1994, p. 938-939).

Trabalhada pelas mãos do pai e do padre, a alma de Murilo estava preparada para a maior de todas as metamorfoses. E esta viria com a aparição do outro cometa que riscaria sua vida: a "personalidade bravia, superior e trágica” do pintor, arquiteto, filósofo outsider, poeta e dançarino paraense Ismael Nery, "príncipe da Renascença que o grupo de seus amigos chegados cortejava como a um rei, indiscutia como a um gênio e seguia como a um demiurgo". (apud GUIMARÃES, 1986, p. 28 e ss).

\section{LIBERDADE DENTRO DA FÉ}

Murilo conhece Ismael em 1921, um ano após haver-se mudado em definitivo de Juiz de Fora para o Rio de Janeiro, a convite do irmão mais velho, a fim de trabalhar como arquivista na Diretoria do Patrimônio Nacional. Vivia então "na faixa do relâmpago", de paixão em paixão, de arte em arte, embriagado de beleza, sem conseguir fixar-se em nenhuma ocupação. Dionísio em pessoa. Recém-chegado de Paris, onde se estabelecera para um período de estudos em artes, Ismael é nomeado desenhista da seção de arquitetura e topografia do Patrimônio Nacional, tornando-se vizinho de repartição de Murilo: "Vi um belo dia entrar na sala um moço elegante e bem vestido. Ajeitou a prancheta, sentou-se e começou a desenhar."(GUIMARÃES, 1986, pp. 28-29). A amizade à primeira vista se prolongaria até a morte precoce do pintor, em 1934, episódio que precipitaria o reencontro de Murilo com a fé católica.

Criador de alta envergadura, artista múltiplo e atualizado com as principais linhas de vanguarda, "Nijinski da conversação", dotado de inteligência translúcida capaz de demorar-se em profundidade sobre os mais diversos assuntos, com uma visão consistente e abrangente sobre a vida, Ismael Nery logo atrairia em torno de si um grupo de ardorosos 
admiradores, entre os quais, além de Murilo, contavam-se Aníbal Machado, Mário Pedrosa, Dante Milano, Guignard e outros, que varava noites em intensa boemia intelectual, cultivando intermináveis discussões sobre a arte e a vida, fazendo incursões ruidosas por teatros, hostilizando o ambiente bem pensante da burguesia carioca.

Ocorre que, além de ícone de vanguarda e livre pensador, Ismael também era católico fervoroso, prostrado de amores pela pessoa do Cristo - a quem se referia como "o Amigo" -, de vida sacramental assídua, frequentador do Mosteiro de São Bento e do Centro D. Vital, agindo e pensando em fina sintonia com a mais clássica ortodoxia da fé cristã católica. Esse contraste deveria intrigar os infants terribles à sua volta, considerando o histórico fechamento da instituição católica às inovações modernas, e a animosidade da ampla maioria dos artistas modernos para com o campo clerical. No entanto, desconcertando expectativas e embaralhando identidades, Ismael Nery fura o cerco antinômico e instaura na cena cultural brasileira de então a improvável aparição de um católico ortodoxo de vanguarda: "Era possível ser em 1930 grande artista, homem moderno e católico romano de confissão frequente. Assim foi Ismael Nery."(MENDEs, 1996, p. 28).

Trocando em miúdos, diz Murilo:

Foi-me dado realizar uma experiência notável: assistir de perto à vida de um místico moderno, circulando nas ruas, nos cafés, nos teatros, nas repartições, procurando extrair de tudo o interesse da verdade religiosa, técnico em adaptação de teorias atuais aos postulados católicos, lutando com um temperamento de fogo, renunciando ao sucesso e às conquistas temporais, fazendo um apostolado inteligente no meio de escritores, poetas e artistas. (Mendes, 1996, p. 134).

Assim, o católico Ismael Nery era ortodoxo quanto às matrizes geradoras de sua fé, mas nem por isso menos inquieto e crítico de pensamento; docilmente filiado a sua tradição espiritual, mas aventuroso na experimentação do novo; curvado ante a autoridade do Mistério, mas insurgente contra tudo o que impedisse a criação de cumprir o seu fluxo. Ismael inventava a figura do católico não reacionário:

Ismael era o oposto do catolicão, deste tipo antipático e ridículo, cujas atividades se reduzem em ir à missa, falar mal do comunismo e se escandalizar com os banhos de mar. Espírito incomparavelmente rebelde, portador de terríveis atavismos, viu desde cedo na solução cristã a única saída para a aventura da existência, cuja intensidade trágica experimentou e conheceu como poucos. Idem. (apud BARBOSA e RODRIGUES, 2009, p. 102).

Por outro lado, o vanguardista Ismael Nery levou o mais longe que pode o vigor autoral do artista e as possibilidades inventivas da arte, derrubando barreiras mentais, morais e institucionais para dar livre curso à criação, sem nada retroceder na pertença à sua fé. Inventava, também, a figura do vanguardista não anticlerical: 
A nota dominante de nosso grupo era sem dúvida o inconformismo. Inconformismo diante do estilo chato da vida burguesa, diante das manifestações estéreis ou acadêmicas da arte e da religião. Inútil acrescentar que éramos todos anticlericais, exceto o avançado e moderníssimo Ismael Nery! (MENDES, 1996, p. 68).

Em suma, Ismael dava a Deus o queé de Deus, e à arte o que é da arte.

O "místico moderno" foi, portanto, um exímio conciliador, operando a relação entre os contrários não no plano da contradição, mas do contraste. Não por acaso, o amigo Murilo afirma em "O Discípulo de Emaús”, obra a ele dedicada: "Um grande artista deve conciliar os opostos”. (MENDES, 1994, p. 822).

Ao passo que a contradição - lógica - separa os polos, implicando a disputa de cada um pela hegemonia da relação; o contraste - logos estético - suporta a tensão da relação enquanto tal e incita a mútua fecundação dos polos, dando lugar ao nascimento do novo não redutível a nenhum destes. No caso de Ismael, o novo em questão é a nova identidade católica - aberta à reinvenção no tempo - e a nova identidade moderma - enraizada na custódia do eterno.

Ismael concilia, pois, tempo e etermidade: “(...) apesar de mergulhado no espírito de seu tempo, não se deixou absorver por ele, mas procurou sempre extrair o eterno do transitório.” (MENDES, 1996, p. 110).

E: "Poucos homens conheci, como Ismael Nery, predispostos a fixarem ao mesmo tempo a modernidade e o permanente, pois sua vida se resume na conquista do essencial através de sucessivas mudanças.” (MENDES, 1996, p. 108).

Concilia, ainda, invenção e tradição: "Mostrou-nos a fecundidade da tradição católica e sua plasticidade dentro da rigidez de princípios imutáveis.” (MENDES, 1996, p. 83).Concilia, enfim, estética e religião: "Para ele a vida estética não se opunha à vida filosófica ou religiosa. Vimos diante de nós, realizado, o ideal grego, desenvolvido e completado pela filosofia cristã. Vimos este milagre: um teólogo que dança!" (MENDES, 1996, p. 98).

Subversor de antinomias, outra inestimável contribuição de Ismael Nery para que Murilo se reaproximasse da fé católica foi haver desconstruído a representação de um Deus “corregedor da moral e severo guardião da lei” (MENDES, 1994, p. 974), apresentando em Cristo o Deus-Companheiro a caminho e em diálogo com o ser humano, que age no tempo em favor de sua permanente renovação:

[...] a ideia de Deus se nos apresentava, em geral, desagradável. Deus não passava de um julgador, um espião de nossos atos, um bedel segurando a palmatória. Chegados à maioridade, nós queríamos logo nos descartar, o mais breve possível, desse 
incômodo personagem: esse Deus positivamente não tinha parte conosco, sendo alheio aos nossos projetos e ao nosso desejo de libertação. Ismael recolocou em nosso espírito a ideia de Deus, ou melhor, instaurou-a em bases artísticas, afetivas ou filosóficas, principalmente através da Encarnação do Cristo prolongada na Igreja e nos homens, na vida de cada dia. [...] De fato, a Encarnação do Cristo é a irrupção da eternidade no tempo. [...] Surgia-nos o Cristo como companheiro cotidiano do homem, seu guia no tempo e na eternidade [...] Surgia-nos o Cristo como o artista máximo, o criador de um grande estilo de vida. (MENDES, 1996, pp. 42-43).

A metanoia que se preparava em Murilo sob influxo de Ismael afinal irrompe com a morte deste, treze anos após haverem se conhecido. Enquanto velava o corpo do amigo, de madrugada, em companhia de pessoas mais íntimas ao morto, o poeta prorrompe num monólogo febril que se torna cada vez mais alto e ininterrupto, intercalado por gritos, até socar o peito e exclamar "Deus!", caindo em profundo silêncio que dura mesmo após o enterro. Recolhe-se, depois, ao Mosteiro de São Bento por três dias, de lá saindo (re)convertido ao catolicismo. Instado durante o velório a medicar o poeta, que julgavam tomado de crise nervosa, o Dr. Pedro Nava se detém: "O que ele está é sendo arrebatado num êxtase e o que estou vendo é o que viram os acompanhantes na estrada de Damasco quando Saulo rolou do cavalo e foi fulminado pela luz suprema.” (apud GUIMARÃES, 1986, p. 33).

Sob o abaciado do teólogo D. Thomas Keller e a renovação litúrgica comandada por D. Martinho Michler, o Mosteiro de São Bento do Rio de Janeiro jogará papel decisivo na consolidação do substrato espiritual e teológico do recém convertido. No entanto, ao de lá sair após o breve retiro, o poeta não deixa em sua soleira o espírito criador, inventivo, insubmisso, rebelde, irreverente, mas a pretensão de encontrar por si mesmo a fonte do sentido. Não abandona a liberdade, mas a autossuficiência. Não sacrifica Dionísio, mas o oferece a Cristo. Não despreza as forças vivas que atuam no mundo, mas passa a considerá-las do ponto de visto do eterno. Como o mestre Ismael, doravante Murilo não recusa, mas transfigura a modernidade a partir da fé cristã. Não contrapõe liberdade e fé, mas promove sua comunicação vital, dando prosseguimento a uma transformação fulcral no catolicismo brasileiro cujos desdobramentos ainda estão em curso. Como assinala Alceu Amoroso Lima: "Foi esse sentido de liberdade, dentro da Fé e da Igreja, que Ismael e Murilo, aquele passando, e este ficando, trouxeram sem alarde para o moderno catolicismo brasileiro.” (LiMA, 2000, p. 176).

E: “Tanto Murilo Mendes quanto Ismael Nery são precursores, entre nós, de um movimento sísmico, sem ruptura, mas com distinções importantes no catolicismo mundial e não apenas brasileiro.” (LIMA, 2000, p. 174). 


\section{TEOPOÉTICA TRANSMODERNA}

São algumas vibrações desse "movimento sísmico" que examinaremos a partir de agora, tendo como fio condutor os aforismos de "O Discípulo de Emaus" (1945), obra inspirada em Ismael Nery e a ele dedicada. Fazendo uma costura conceitual seletiva dos aforismos, resumiremos o pensamento teopoético transmoderno de Murilo Mendes, a partir da breve exposição dos seguintes núcleos conceptivos: transcendência e essência; modernidade estéril; modernidade fecunda; espiritualidade encarnada; cristocentrismo; poética cristã.

\subsection{TRANSCENDÊNCIA E ESSÊNCIA}

Desde os "Poemas" de estreia, um dos traços mais recorrentes na obra de Murilo Mendes é o afã de transcendência, isto é, a busca de uma dimensão além - outra - que o sujeito não pode dar a si mesmo e sem a qual, entretanto, não pode decifrar-se. Nas palavras de Rimbaud: “A verdadeira vida está ausente”. (apud LEVINAS, s/d, p. 21). O afã de transcender torna patente a radical insuficiência e insolubilidade do ser humano, incapaz de responder por si à questão de vida ou morte que traz e é. Noutras palavras, o ser humano não é constituído à medida de si mesmo - ainda está por nascer: "Nascerei em outras terras, com olhos novos./ (...) Me desdobrarei em planos infinitos, estarei nos olhos da criança nascendo,/ na cabeça dos amantes, nos degraus do espaço,/ na última luz dos velhos morrendo, no sonho do místico,/ e em todos os lugares onde existir alguém sofrendo e amando.” (MENDES, 1994, p. 107).

Em Murilo, a transcendência em geral aparece como libertação do tempo: "Um dia a morte devolverá meu corpo,/ estes olhos verão a luz da perfeição/ e não haverá mais tempo." (MENDES, 1994, p. 108).O poeta associa a eternidade à "visão" da perfeição, como se tisnasse o tempo uma originária opacidade que nos impede contemplar o mistério para o qual fomos criados: "E ilumina-nos fora do tempo, a todos nós/ Que esperamos tua divina Parusia." (MENDES, 1994, p. 251). No último aforismo de "O Discípulo de Emaús", isto é dito de outro modo: "O homem é um ser futuro. Um dia seremos visíveis." (MENDES, 1994, p. 891. Grifo nosso). Enquanto não raia o "dia” eterno, resta o "mundoenigma" e o enigma que somos para nós mesmos. Em "Saudação a Ismael Nery", o "Ente magnético" (Cristo?) "acima dos cubos verdes e das esferas azuis", é assim descrito: "Ele pensa desligado do tempo,/ as formas futuras dormem nos seus olhos./ Recebe diretamente do Espírito/ a visão instantânea das coisas, ó vertigem!/ penetra o sentido das ideias, das cores, a totalidade da Criação,/ olho do mundo,/ zona livre de corrupção, música que não para nunca,/ forma e transparência.” (MENDES, 1994, p. 115). Outra vez,

\footnotetext{
${ }^{9}$ Título do livro de poemas de Murilo Mendes publicado em 1942. 
"visão instantânea", "sentido das ideias" e "transparência" - enfim, revelação - nessa dimensão desligada do tempo. Note-se, entretanto, que a transcendência também se comunica como "música que não para nunca”: é libertação da visão e do ritmo/melodia; iluminação e elã. Aliás, amiúde reafirma-se em Murilo essa dimensão iniciática atribuída à música: "Poucos captarão a melodia eterna, fundamento da música, essência pura, contemplação sobrenatural do universo". (MENDES, 1994, p. 881). Dito pelo avesso: "No inferno não há música.” (MENDES, 1994, p. 881).

Se a eternidade é revelação de essências, a transcendência passa pela libertação das formas provisórias:

Entre a eternidade e o meu espírito/ se balança o mundo das formas./ [...] Estou aqui, nu, paralelo à tua vontade,/ sitiado pelas imagens exteriores./ Todo o meu ser procura romper o seu próprio molde/ em vão! noite do espírito/ onde os círculos da minha vontade se esgotam./ Talhado pra eternidade das ideias/ ai quem virá povoar o vazio de minha alma?/ [...] Me desliguem do mundo das formas! (MENDES, 1994, p. 106).

No viés metafísico - de nítido acento platônico - que inspira os versos, a precariedade do tempo mais tem a ver com impossibilidade de contemplar a verdade eterna, que com misérias e mazelas da condição mortal; é antes angústia pelo "vazio da alma" que sofrimento pelos males da carne. Nesse sentido, a grande limitação imposta pelo tempo, ainda maior que a morte, é a cegueira espiritual.

Nessa linha contemplativa, a transcendência é, ainda, libertação das contradições que laceram o ser humano: "Deram-me um corpo, só um!/ Para suportar calado/ Tantas almas desunidas/ Que esbarram umas nas outras,/ De tantas idades diversas (...)/ Ó Deus, se existis, juntai/ Minhas almas desencontradas.” (MEndES, 1994, p. 207). Também aqui, o poeta se fia na luz eterna para religar-se à secreta unidade que sustenta todas as coisas: "Dilata minha visão,/ Dilata poderosamente minha alma,/ Faze-me referir todas as coisas ao teu centro,/ Faze-me apreciar formas vis e desprezíveis,/ Faze-me amar o que não amo.” (MENDES, 1994, p. 251).

Enfim, embora passe pela conciliação consigo mesmo, a transcendência é, em última instância, libertação de si mesmo:

Senhor do mundo,/ cada vez que ressuscitas um homem, me destruo a mim mesmo./ [...] Enquanto te multiplicas na humanidade/ não saio dos limites de minha pessoa./ [...] / Senhor do mundo,/ me tira de mim pra que eu possa olhar os outros e eu mesmo. (MENDES, 1994, p. 107).

Libertação do tempo - para a eternidade; das formas mutáveis - para a essência; da contradição - para a unidade; de si mesmo - para os outros e o absoluto Outro. Aqui já não está em jogo a obra de "liberação" antes referida à modernidade, mas já se trata de 
libertar a própria liberdade ou - como diz Levinas - de dar ao sujeito uma (outra) luz para ver (e julgar) a sua própria luz. A verdadeira vida está ausente. (LEVINAS, 1988, p. 21).

A articulação de eternidade, essência e unidade imprime-se na poesia de Murilo Mendes como um selo de filiação ao pensamento do mestre Ismael Nery, cujo essencialismo - filosofia extra-acadêmica que este preferia ver como mera propedêutica à doutrina católica - baseia-se "na abstração do tempo e do espaço, na seleção e cultivo dos elementos essenciais à existência, na redução do tempo à unidade, na evolução sobre si mesmo para a descoberta do próprio essencial, na representação das noções permanentes que darão à arte a universalidade.” (MENDES, 1996, p. 65).

Em resumo, essencialismo como método para alcançar a unidade espiritual (e o equilíbrio humano/estético) a partir da assimilação aos elementos essenciais que assegurem a remissão do tempo à eternidade.

\subsection{MODERNIDADE ESTÉRIL}

Imantado à dimensão subversiva da personalidade do poeta, esse vetor contemplativo de sua obra perde qualquer inofensivo sentido evasivo ao inspirar uma desconstrução profética da civilização moderna, confrontada na perspectiva de seu esterilizante fechamento à transcendência. Nas palavras de Heidegger: "Talvez o elemento mais marcante desta idade do mundo consista no rígido fechamento à dimensão da graça. Talvez seja esta a única desgraça.” (HEIDEGGER, 1973, p. 366).

Ao passo que no mundo antigo "tudo era comunicação, alegoria e crença", a civilização moderna "está repleta de alfabetizados e mecânicos que não compreendem o espírito poético do mundo." Trancado em sua subjetividade e cioso da certeza como critério suficiente de verdade, o homem moderno "enxerga tão pouco, que chegou à inesperada conclusão que não existe mistério.” Por isso, "a esperança está nos cegos." (MENDES, 1994, p. 847).

A civilização técnico-industrial atenta contra o espírito da vida erodindo as fontes da criação, pois "só faz a apologia do trabalho exagerado quem não pode criar." (MENDES, 1994, p. 840); e - especialmente na ordem burguesa - opondo-se à redenção propiciada pela "Revolução das Bem-Aventuranças" (MENDES, 1994, p. 834), pois a utópica charitas ameaça os fundamentos de uma sociedade organizada em torno da produção e do consumo. Fechado ao mistério e avesso à criação, inimigo de charitas e de eros - de tudo, enfim, que é gratuito -, entende-se porque, ao mesmo tempo, "o homem burguês não crê na Transubstanciação" (MENDES, 1994, p. 819) e "não existe nada mais dentro de um conceito lógico que o desprezo do rico pelo poeta.” O “espírito pesado” - que tudo calcula e 
a tudo acumula - é, pois, a uma só vez "antireligioso, antimusical, antipoético." (MENDES, 1994, p. 846). Murilo, ao invés, proclama: “A vida não é apenas um campo de observação e experiência técnica; é também um campo de improvisação, de fenômenos, prazeres e sensações antipráticos, de inesperadas metamorfoses, de audácia espiritual. Operemos a síntese da loucura.” (MENDES, 1994, p. 835).

Em suma, “o mundo moderno precisa ser vomitado.” (MENDES, 1994, p. 833).

\subsection{MOdERNIDAdE FECUNDA}

No entanto, o poeta sabe separar o joio moderno das sementes de futuro latentes nos movimentos de liberação estética e social. Não foi, como vimos, nem de longe um antimoderno reativo, mas investiu nas virtualidades utópicas de seu tempo:

Não desejamos a volta do homem medieval. Desejamos a instauração do homem ajustado à sua vocação e aos seus objetivos, de cultura mais harmônica que especializada, semeando no tempo para colher na eternidade, concidadão de todos os seres e herdeiro consciente da promessa divina, homem supranacional que não confunde a cultura com a técnica, nem o valor com dinheiro. Queremos o homem novo que não põe os seus fins em si mesmo. (MENDES, 1994, pp. 834-835).

Assim, mesmo não perdendo de vista a eternidade do essencial - ou por isso mesmo -, o autor de "Poesia Liberdade" crê no advento do "homem novo", fia-se na dinâmica rejuvenescedora do tempo: "Tudo o que é genuíno e simples contém um elemento novo e revolucionário”. (MENDES, 1994, p. 862). E porque nenhuma transformação histórica é suficiente para a obra de nascimento do humano, "só o futuro é moderníssimo" (MENDES, 1994, p. 833) - e o futuro está sempre adiante. Grande "conciliador de opostos”, o poeta opera a transfusão das eras, enraizando a energia da modernidade na insondável profundidade da tradição judeu-cristã, ampliando ao infinito o seu horizonte utópico: "Sinto-me antiquíssimo - e sinto a era futura debater-se impaciente em mim." (MENDES, 1994, p. 891).

Como vimos, é sobretudo em campo estético que se torna patente o acordo de Murilo com os tempos modernos: "A regra de ouro cria a necessária disciplina; mas existe também uma regra de ouro da liberdade.” (MENDES, 1994, p. 849). Mais que desobstruir o vigor criativo da subjetividade, porém, a insurreição da estética moderna remete à criação como ato constitutivo da própria realidade: "A poesia é a realidade; a imaginação, seu vestíbulo." (MENDES, 1994, p. 830). Em última instância, "Só não existe o que não pode ser imaginado." (MENDES, 1994, p. 886). Nesse sentido, "todo pintor visionário é antes de tudo um grande realista." (MENDES, 1994, p. 849) e a Natureza, ela mesma, "é muito surrealista.” (MENDES, 1994, p. 849). Por isso, em arte, doravante o importante é 
"possuir a imaginação da cor ou do desenho - não do assunto" (MENDES, 1994, p. 850), e romper com a subserviência a este torna-se a prova dos nove do autêntico criador: "Para o pintor medíocre a libertação do assunto, provocada pelos movimentos de arte moderna, constitui um embaraço." (MENDES, 1994, p. 849). No entanto, se a arte autêntica é ruptura de amarras, ela é antes sujeição ao moto lírico que comanda o gesto da linguagem e impõe o expurgo das formas espúrias do dizer. A grande arte acontece, portanto, em voz passiva: "Há o homem que dança e o que é dançado. O verdadeiro dançarino é dançado." (MENDES, 1994, p. 878). Eé por assim conciliar ruptura e sujeição, liberdade e obediência, e guardar a graça da criação, que a arte está destinada a servir de princípio pedagógico à nova civilização antitecnocrática: "A escola futura deverá ser a base poética. Senão, servirá à burocracia e à guerra.” (MENDES, 1994, p. 865).

Tomada às últimas consequências, a estética revela-se via de transcendência: "O poeta é o prático do espiritual.” (MENDES, 1994, p. 888).

\subsection{ESPIRITUALIDADE ENCARNADA}

Ora, "no plano poético, o espiritual é orgânico." (MENDES, 1994, p. 848. Grifo nosso).Por inequívocas que sejam as reverberações platônicas do essencialismo legado do mestre Ismael Nery, não há em Murilo Mendes uma visão propriamente dualista. A transcendência - o além - deixa atrás de si o despojo de certezas e controles do sujeito saturado de si mesmo, mas permanece nutrindo-se da vida de sua carne, pois o corpo "é um oráculo" (MENDES, 1994, p. 827) e "pelos cinco sentidos também se vai a Deus." (MENDES, 1994, p. 826). Outra lição da arte moderna que Murilo leva longe - com o inestimável contributo do mistério cristão da Encarnação - é o insondável e indissolúvel enlace de carne e espírito, sensível e sentido, visível e invisível, na criação artística e no mais. A arte resguarda a terra em sua consistência própria - a densidade mineral, o brilho da luz, o tom do som $-{ }^{10}$, recolhendo a seiva sensível de sentido para a comunicação metafórica/metafísica: “A matéria é forte e absoluta./ Sem ela não há poesia.” (MENDES, 1994, p. 297). Noutras palavras, no mundo físico "existem muito mais símbolos e alegorias do que na Escritura." (MENDES, 1994, p. 846), e "o universo é a oficina da cultura transcendente.” (MENDES, 1994, p. 886).

Dentre os "elementos" do cosmos, um, em especial, destaca-se: "Existem cinco elementos: o ar, a terra, a água, o fogo e a pessoa amada." (MENDES, 1994, p. 885). Basta um ligeiro passeio pela poesia androcêntrica do autor de "Metamorfoses", para dar-se conta de que "a pessoa" a que se refere é a mulher amada. E poucos poetas de nossa

\footnotetext{
${ }^{10}$ Sobre o conceito estético de "terra", ver HEIDEGGER, Martin. A Origem da Obra de Arte. Lisboa: Edições 70, s/d.
} 
literatura, de fato, terão amado mais a mulher e melhor conhecido seus meandros que este afortunado filho de Juiz de Fora, cujas iniciações aos segredos do sexo oposto são generosamente pontuadas nas páginas autobiográficas de "A Idade do Serrote”:

Uma certa noite, achando-me a sós, ela me atacou, beijando-me e mordendo-me furiosamente a boca, o braço, os ombros. $\mathrm{O}$ sangue galopava nas minhas veias. $\mathrm{O}$ cheiro do seu corpo colado ao meu punha-me em frente à matéria viva, imediata, e eu nesse momento intuía que nada era mais importante que a matéria. (MENDES, 1994, p. 945).

Murilo extrai de sua ginofilia as mais amplas consequências estéticas, como se a mulher fosse a síntese da criação e encerrasse em si todas as metáforas: "A mulher é o grande campo artístico do homem.” (MENDES, 1994, p. 823). Amada a fundo em "maquilagens", “joias", "perfumes”, "peitilhos”, "seios”, "ventres”, com seus feitiços e fascínios, a fêmea-maga, entretanto - ou por isso -, espicaça a ânsia de eterno que consome o poeta: "Tudo o que te rodeia e te serve/ Aumenta a fascinação e o enigma." (MENDES, 1994, pp. 292-293). Elemento do cosmos, substância da poesia, a mulher está "em todos os lugares". (MENDES, 1994, p. 308). Seu corpo "liga o céu e a terra" (MENDES, 1994, p. 301) e - outro livro místico, no melhor estilo John Donne - encerra a chave que abre a fonte do mistério: "És, talvez sem querer, o laço enigmático/ Que me prende à ideia essencial de Deus.” (MENDES, 1994, p. 308). Por isso, não estranha que o poeta veja a insurgência do feminino como portal de passagem à civilização chamada a nascer para além da modernidade: "A mulher determina continuamente no mundo uma transformação maior do que todas as revoluções.” (MENDES, 1994, p. 886).

\subsection{CRISTOCENTRISMO}

$\mathrm{O}$ advento desse novo sentido do humano constitui uma das pedras de toque de " $\mathrm{O}$ Discípulo de Emaús”. De saída, Murilo marca distância do paradigma moderno por não conceber o humano senão em sua referência a Deus: "A vida humana é um código, mas Deus nos fornece elementos para decifrá-lo.” (MENDES, 1994, p. 825). Nesse sentido como já vimos -, medimo-nos com o infinito e somos chamados a suportar a passagem para além de nós mesmos: "Grande coisa é assumir a humanidade, e maior coisa ainda, libertar-se dela." (MENDES, 1994, p. 854). Reduzida ao seu poder de escolha, a liberdade não teria como aviar o caminho de sua realização, permanecendo enredada no labirinto das possibilidades e nas infindáveis seduções que ameaçam subjugá-la ao arbitrário. A autenticidade - tão sabiamente cultivada na estética moderna - é uma exigência básica a ser assumida, mas não basta para construir o habitat humano. Por isso, em última instância, "o cúmulo do livre-arbítrio consiste em poder abandoná-lo.” (MENDES, 1994, p. 879); e, de modo análogo, a inteligência "torna-se fecunda quando começa a reconhecer os 
seus limites." (MENDES, 1994, p. 879). Assim, o ser humano "mais refinado" é "o pobre em espírito" (MENDES, 1994, p. 833), justamente por assumir a própria insuficiência em sua errância entre luz e trevas. Afinal, pode-se até ser "muito espiritual, e nada celeste". (MENDES, 1994, p. 828). Com efeito, o espírito - ou a consciência, ou a ciência - não é conatural ao bem. Não sabe tudo o que deve querer, nem quer tudo o que sabe que deve. A desgraça acompanha-o como uma sombra. No entanto, tampouco basta o auxílio da “muleta moral" (MENDES, 1994, p. 886) para deparar o caminho. Não tanto pelo estrito metro das regras impostas, quanto pela atitude defensiva que previne os precipícios ao preço de empobrecer a travessia do caminho: "A moral é a filosofia do instinto de conservação." (MENDES, 1994, p. 817). Assim, “aperfeiçoar a vida interior não é apenas uma questão de moral: é também uma questão de ritmo.” (MENDES, 1994, p. 857) - isto é, de se abrir à secreta pulsação da vida ou afinar-se com o logos que preside todas as coisas.

Chama a atenção, em Murilo, a transposição de categorias estéticas ao campo espiritual, como se a liberdade encontrasse sua justa medida menos na sujeição a regras de boa ação que no cultivo de uma suprema arte de bem viver: "Só pelos místicos, pelos músicos e pelos poetas se poderá restaurar a melodia da estrutura humana." (MENDES, 1994, p. 881). Dito em termos negativos: “Antes de atacar a moral”, por exemplo, “o impudor ataca a poesia.” (MENDES, 1994, p. 833). Semelhante arte de viver atinge sua mais elevada maturação na charitas, "antitécnica por excelência" (MENDES, 1994, p. 833), na qual o desejo, libertado do aprisionamento a si mesmo, afinal quer o que deve e, por graça, pode o que quer, como se de novo tomado pela originária "melodia" do humano. "Anárquica por definição", quando a caridade "se alastrar e atingir a intensidade máxima, o mundo pegará fogo. A ordem será então inútil por si mesma.” (MENDES, 1994, p. 852).

Como terá soado esse ousado vaticínio nos ouvidos dos zeladores eclesiásticos da Ordem?

Ora, é essa poética da caridade que encontra a sua suma no “espírito de Emaús”, o qual

é o contrário do espírito de gabinete e de laboratório: é o espírito antitécnico, de desprendimento, de improvisação e de fraternidade no essencial. A vida poética pela contemplação das obras divinas, pelo aprofundamento da Escritura, o companheirismo, o céu aberto, o pão eterno, uma posta de peixe e um favo de mel. É o complemento e a plenitude do espírito do Sermão da Montanha, o mais alto e perfeito exemplo de vida poética jamais proposto aos homens. (MENDES, 1994, p. 838).

O trecho refere-se ao episódio narrado no Evangelho de São Lucas no qual, três dias após a crucificação, o Ressuscitado aparece a dois desanimados discípulos que rumam ao 
povoado de Emaús, explicando-lhes as Escrituras enquanto caminham. À voz do Rabi, o coração dos caminhantes "arde". Ao cair a noite, recolhem-se a um casebre nas proximidades de Emaús e, ao partir o pão na ceia, afinal O reconhecem, mas Ele se torna invisível e desaparece. (A BİBLIA SAGRADA, 2002, pp. 1382-1383). Apresentado por Ismael Nery nas estradas tortuosas do século XX, esse Deus-Companheiro - que partilha a estrada, a palavra e o pão - é nada menos que o centro de gravidade do pensamento teopoético de Murilo Mendes e supremo ponto de convergência das tantas dimensões terra e céu, carne e espírito, visível e invisível - que tentou conciliar: "Na encarnação de Jesus Cristo realizou-se o fato único e prodigioso do encontro entre a vocação homocêntrica de Deus e a vocação teocêntrica do homem.” (MENDES, 1994, p. 869). Deus-Homem, Homem-Deus, nEle - e somente nEle - a desmedida do enigma humano encontra sua definitiva resposta: "Cristo decifra o homem." (MENDES, 1994, p. 855). Criador de todas as coisas que se faz carne e comida, Cristo é o "grande sacramento do Universo" (MENDES, 1994, p. 841) e consuma as forças gerativas em ação no cosmo; Senhor da história que faz morada na história de um povo, Ele "funde os tempos e descerra a eternidade.” (MENDES, 1994, p. 869); Redentor do ser humano em suas mais diversas dimensões e áreas de ação, Cristo é, enfim, "a civilização”. (MENDES, 1994, p. 885).

\subsection{POÉTICA CRISTÃ}

“Artista máximo", Cristo oferece à pletórica idade moderna um "grande estilo de vida" (MENDES, 1994, p. 851) que lhe falta, cujo gracioso sprit de finesse $e^{11}$ o poeta Murilo soube captar em inusitados ângulos, a exemplo deste em que se mostra Sua divina discrição: "A suprema delicadeza de Jesus Cristo consiste em ter ocultado até o último instante sua Divindade.” (MENDEs, 1994, p. 818). Com efeito, a "invisibilidade é um dos mais belos atributos de Deus" (MENDES, 1994, p. 823), pois "os homens são de mais, e Deus de menos." (MENDES, 1994, p. 821). Outro elegante chiste do Mestre é haver "abalado a lei do tempo", desfazendo a suposta relação entre idade cronológica e estatura espiritual: "Aos doze anos mostrou sua madureza, e na idade madura pregou o espírito de infância.” (MENDES, 1994, p. 839). Realçando a graça do Cristo na perspectiva da franca alegria, sem descurar os mistérios redentores da Paixão, Murilo cobra que não se perca de vista nos evangelhos os momentos de gratuito gozo telúrico partilhado pelo Rabi junto aos seus:

É bom acompanhá-lo nos seus vastos raidspelos campos e pelo mar da Galileia; cultivar o prazer da conversa com Ele no templo, no pórtico de Salomão; beber o

\footnotetext{
${ }^{11}$ Não obstante a categoriapascaliana, cumpre ressalvar que Murilo Mendes em nada carrega o jansenismo que, de modo tão vigoroso, marca o pensamento de Pascal.
} 
vinho, comer com Ele o pão, o peixe, o favo de mel; cantar hinos; e estabelecer amizades de sólida ternura, cujos modelos eternos são Lázaro e Madalena; viver, enfim, o grego que também existe na universalidade da sua Pessoa. (MENDES, 1994, p. 875).

Nas antípodas do Cristo telúrico, que se demora à mesa, vira água em vinho e dá-se à festa - “o demônio é o ente que não brinca.” (MENDES, 1994, p. 887).

A partir dessa compreensão do Evangelho como poética espiritual, Murilo não deixa de frisar a dimensão estética da própria tradição católica, que, ao menos em seu tempo, parecia esquecida: "A caridade é muito mais elástica do que rígida. Daí a admirável plasticidade do catolicismo." (MENDES, 1994, p. 865). Por isso, "Só o catolicismo pode se transformar continuamente, ficando igual a si mesmo.” (MENDES, 1994, p. 842). A própria doutrina católica, cuja sólida arquitetura dogmática inspira aversão a tantos livres pensadores, resulta "supremamente elegante" (MENDES, 1994, p. 838) aos olhos do poeta. Afinal, para ele o "espírito de ortodoxia”, ao contrário de estreito ou obtuso, implica "ou uma grande simplicidade, ou uma grande inteligência, ou então as duas qualidades reunidas." (MENDES, 1994, p. 845). Quanto à santidade, desconstruída em perspectiva nietzschiana como sintoma de ressentimento contra a vida, enquanto expressão do ideal ascético, Murilo a descreve à luz do mesmo excepcional sprit de finesseatribuído a Cristo: "O dandismo é a elegância natural; a santidade é o dandismo sobrenatural." (MENDES, 1994, p. 821). O santo - o místico - é, por excelência, o poeta de Deus, aquele no qual eros transfigura-se em charitas, como Murilo havia testemunhado em Ismael Nery. Enfim, o cristianismo "é desmesurado dentro de equilíbrio." (MENDES, 1994, p. 839): nele o fogo criador de charitas, sem chegar a domar-se, dá lugar a uma nova medida que permite à vida continuar a gerar e regenerar-se. Aqui, Dionísio e Apolo, transfigurados, alcançam em Cristo nova conciliação.

Pelo exposto, Murilo chega a afirmar que o combate ao catolicismo "pode ser também uma ação política, mas é antes de mais nada uma ação antipoética." (MENDES, 1994, p. 851. Grifo nosso).

A maior ameaça ao catolicismo viria, paradoxalmente, do próprio campo católico, dos que reduzem a poética do Evangelho a formulário doutrinário e exaurem seu elã criador sob a imposição de rígida ordem normativa: "A carolice pode causar à religião maiores estragos do que o próprio ateísmo.” (MENDES, 1994, p. 839).

Talvez devido ao ostensivo predomínio dessa cultura "carola" nos meios católicos da época, reforçado pela reação eclesiástica aos ventos dos novos tempos, Murilo se desliga da Ação Católica apenas seis meses após nela haver ingressado a convite de Alceu Amoroso Lima, alegando "só sentir-se católico entre os não-católicos". (GUIMARÃES, 1986, p. 51). Note-se que o poeta não diz só sentir-se "bem", mas "católico", como se a 
experiência de abertura à pluralidade de algum modo concernisse ao exercício de sua fé. Embora por um tempo ainda tenha se nutrido da espiritualidade beneditina e continuasse a frequentar a Conferência Vicentina para não perder contato com os pobres, ao que tudo indica o ambiente confessional mediano resultava-lhe inóspito, e ele parecia mais à vontade entre os irmãos de arte do que de credo.

Quem sabe a própria Igreja da Ordem ainda não estivesse preparada para acolher o fogo profético desse poeta-cometa desprendido das órbitas institucionais.

\section{CONCLUSÃO}

Murilo Mendes se sobressai como um dos mais inventivos poetas brasileiros contemporâneos de matriz modernista. Por isso, causou estranheza a publicação de "Tempo e Eternidade" (1935), sob o lema "Restauremos a poesia em Cristo", cuja impostação aparentemente reativa sugere haver o poeta renegado sua condição moderna e, ao menos, restringido a vocação artística. Não obstante, conforme atestamos nessa abordagem retrospectiva de sua vida e obra, tal viragem estético-existencial intensifica características estilísticas e abre outras zonas de sensibilidade e horizontes temáticos em sua poesia, operando uma transfiguração simbólica que nem lhe desfibra o élan criador, nem doma sua insubmissa virulência. A "restauração" da poesia "em Cristo" não capitula a liberdade criadora do poeta a uma férrea ordem metafísica prévia, mas propicia-lhe o encontro com uma inaudita potência redentora de sentido que lhe dá novos e definitivos motivos para cantar. Ao conciliar liberdade e fé, criação e reverência e, por extensão, homem e Deus, tempo e eternidade etc., convertendo a suposta contradição em tenso e fecundo contraste, a poesia de Murilo Mendes descortina uma promissora perspectiva de leitura do mistério cristão que aqui denominamos transmoderna, a qual, sem ser antimoderna ou "reacionária" - por assumir a aventura da liberdade na vertigem dos tempos atuais -, vai além do paradigma moderno, ao retirar o sujeito de sua esterilizante autosuficiência e abri-lo a um permanente diálogo com a transcendência.

Assim, ao "trazer a liberdade para dentro da fé", o percurso estético-existencialdo poeta vanguardista traz à luz a intrínseca jovialidade do mistério cristão, cuja linguagem não cessa de se reinventar a cada nova aurora histórica, ao tempo em que aponta para os criadores egressos do modernismo uma fonte inesgotável de sentido a partir da qual o seu ímpeto de libertação é chamado a alcançar sua mais vigorosa afirmação. 


\section{REFERÊNCIAS}

ARAÚJO, Laís Corrêa de. Murilo Mendes - Ensaio Crítico Antologia Correspondência. São Paulo: Ed. Perspectiva, 2000.

BARBOSA, Leila Maria Fonseca e RODRIGUES, Maria Timponi Pereira. Ismael Nery e Murilo Mendes: Reflexos. Juiz de Fora-MG: UFJF/MAMM, 2009.

BÍBLIA SAGRADA. São Paulo: Ed. Ave-Maria, 2002.

GIDDENS, Anthony. Consequências da Modernidade. São Paulo: Ed. UNESP, 1991.

GUIMARÃES, Júlio Castañon. Murilo Mendes. Rio de Janeiro: Ed. Brasiliense, 1986.

HEIDEGGER, Martin. Carta sobre o Humanismo. OS PENSADORES. São Paulo: Ed. Abril Cultural, 1973.

A Origem da Obra de Arte. Lisboa: Edições 70, s/d.

LEVINAS, Emmanuel. Totalidade e Infinito. Lisboa: Edições 70, 1988.

LIMA, Alceu Amoroso. Memórias Improvisadas. Petrópolis-RJ: Ed. Vozes, 2000.

MENDES, Murilo. Poesia Completa e Prosa. Rio de Janeiro: Ed. Nova Aguilar, 1994.

Recordações de Ismael Nery. São Paulo: EDUSP, 1996.

PESSOA, Fernando. "Ficções do Interlúdio". In Obra Poética. Rio de Janeiro: Editora José Aguilar, 1960.

RICOEUR, Paul. História e Verdade. Rio de Janeiro: Companhia Editora Forense, 1968.

VELOSO, Caetano. Álbum "Bicho”: Phillips, Rio de Janeiro, 1977.

Recebido em 23/o5/2016

Aprovado em 05/07/2016 